\title{
ANALISIS PERUBAHAN UNDANG-UNDANG INVESTASI MELALUI OMNIBUS LAW 2020 DAN DAMPAKNYA TERHADAP PERIJINAN INVESTASI
}

\author{
Hanna M. Simanjuntak, Bernard Nainggolan, Wiwik Sri Widiarty \\ Universitas Kristen Indonesia (UKI) Jakarta, Indonesia \\ Email: simanjuntakhannamarlina@gmail.com, bernard.nainggolan@uki.ac.id, \\ wiwik.sriwidiarty@uki.ac.id
}

\begin{tabular}{l}
\hline INFO ARTIKEL \\
\hline Diterima \\
25 Oktober 2021 \\
Direvisi \\
05 November 2021 \\
Disetujui \\
15 November 2021 \\
\hline Kata Kunci: \\
kepailitan; \\
penundaan \\
kewajiban \\
pembayaran utang; \\
homologasi \\
perdamaian; \\
chapter 11 US \\
bankrupty code.
\end{tabular}

ABSTRAK
Hubungan debitur dan kreditur dalam perjanjian utang piutang
menimbulkan suatu perjanjian pinjam meminjam uang yang
menyebabkan adanya suatu perikatan diantara para pihak.

Dengan adanya perikatan maka masing-masing pihak mempunyai hak dan kewajiban. Salah satu kewajiban dari debitor adalah mengembalikan utangnya sebagai suatu prestasi yang harus dilakukan. Perjanjian utang piutang bukanlah menjadi suatu masalah dalam dunia usaha bila antara debitur dan kreditur terdapat konsep pemahaman dalam isi perjanjian dan debitur tetap mampu untuk melakukan pembayaran utang. Permasalahan baru timbul apabila debitur tidak cukup efisien dalam menjalankan roda perusahaan dikarenakan krisis financial dan mengalami kebangkrutan atau yang disebut dengan pailit. Oleh karena itu, bagaimana persamaan dan perbedaan perdamaian menurut Undang-Undang Kepailitan dengan Reorganization Plan menurut Chapter 11 United State Bankruptcy code serta Penerapan Reorganization Plan berdasarkan Chapter 11 United State Bankruptcy menjadi rumusan dalam penelitian ini. Berdasarkan pendapat dari Lawrence terdapat tiga komponen yang menjadi dasar perbedaan hukum antara lain; sistem hukum, subtansi hukum, budaya hukum. Adapun metode penelitian yang digunakan dalam penelitian dengan pendekatan perundangundangan. Pendekatan ini dilakukan dengan menelah semua peraturan perundang-undangan yang berkaitan dengan isu hukum yang akan diteliti. penelitian ini menggunakan data sekunder dengan mengumpulkan data-data berupa peraturan hukum kepailitan dan Chapter 11 serta Chapter 7. Setelah itu, penulis melakukan analisis data. Sehingga menemukan hasil yaitu; terdapat perbedaan sistem hukum Indonesia Undang-Undang Nomor 37 Tahun 2004 tentang Kepailian dan penundaan Kewajiban Pembayran Utang berbeda dengan Chapter 11

$\begin{array}{ll}\text { How to cite: } & \text { Hanna M. Simanjuntak, Bernard Nainggolan, Wiwik Sri Widiarty. (2021) Analisis Perubahan } \\ & \text { Undang-Undang Investasi Melalui Omnibus Law 2020 dan Dampaknya Terhadap Perijinan } \\ & \text { Investasi. Jurnal Syntax Admiration 2(11). https://doi.org/10.46799/jsa.v2i11.338 } \\ \text { E-ISSN: } & \text { 2722-5356 } \\ \text { Published by: } & \text { Ridwan Institute }\end{array}$


Reorganization Plan US Bankrupty Code. Persamann dan perbedaan didasarkan pada adanya sistem hukum yang berbeda Chapter yang menjelaskan tentang Reorganisasi Plan yang pada umumnya disebut sebagai reorganisasi kedua negara menentukan pihak ketiga yang ikut menyelesaikan permasalah yaitu Amerika disebut dengan Trustee dan Indonesia disebut dengan kurator. Penerapan reorganisasi Plan di Amerika Serikat Dalam Chapter 11 yang menjelaskan tentang Reorganisasi Plan yang pada umumnya perusahan yang mengalami kesulitan keuangan memberikan suatu petisi (Petition), (Protection), (Proceeding) yang menjadi tahap-tahap pengajuan permohonan, perlindungan hukum diberikan terhadap pihak yang harus menerimanya serta proses dan ketentuan yang berlaku bagi kreditor dan debitor dalam menyelesaiakan permasalahan utang.

\section{ABSTRACT}

The relationship between the debtor and creditor in the loan agreement gives rise to a money loan agreement which causes an agreement between the parties. With the engagement, each party has rights and obligations. One of the obligations of the debtor is to return the debt as an achievement that must be done. Accounts payable agreement is not a problem in the business world if between the debtor and creditor there is a concept of understanding in the content of the agreement and the debtor is still able to make debt payments. New problems arise when the debtor is not efficient enough in running the company due to the financial crisis and experiencing bankruptcy or what is called bankruptcy. Therefore, how are the similarities and differences between the Bankruptcy Law and the Reorganization Plan according to Chapter 11 of the United State Bankruptcy code and the Implementation of the Reorganization Plan based on Chapter 11 of the United State Bankruptcy into the formulation in this study. Based on Lawrence's opinion, there are three components that form the basis of legal differences, namely; legal system, legal substance, legal culture. The research method used in research with a statutory approach. This approach is carried out by examining all laws and regulations relating to the legal issues to be studied. This research uses secondary data by collecting data in the form of bankruptcy law regulations and Chapter 11 and Chapter 7. After that, the authors perform data analysis. So find the results, namely; There are differences in the Indonesian legal system. Law Number 37 of 2004 concerning Bankruptcy and Suspension of Debt Payment Obligations is different from Chapter 11 of the Reorganization Plan of the US Bankrupty Code. The similarities and differences are based on the existence of a different legal system. Chapters that explain the Reorganization Plan which are generally referred to as the reorganization of the two countries determine the third party 


\begin{tabular}{ll}
\hline Keywords: & who participates in solving the problem, namely America is \\
bankruptcy; & called the Trustee and Indonesia is called the curator. \\
suspension of debt & Implementation of the reorganization Plan in the United States \\
payment & In Chapter 11 which describes the Reorganization Plan, which \\
obligations; & generally companies experiencing financial difficulties provide a \\
homologation of & petition (Petition), (Protection), (Proceeding) which are the \\
peace; chapter 11 stages of submitting an application, legal protection is given to \\
of the US parties who must accept it and the processes and conditions that \\
bankrupty code.
\end{tabular}

\section{Pendahuluan}

Dewasa ini, perjanjian yang sering dilakukan yang berkaitan dengan bisnis dari segi hukum memiliki hubungan yang sangat erat. Artinya hukum yang berperan mengatur kedua pihak yang membuat perjanjian. Dimaksudkan adalah pihak-pihak tersebut harus dapat mendapatkan kesimbangan dalam menjalankan suatu usaha atau kepentingan. Oleh karena itu maka muncul hukum perjanjian yang mendasari keduanya, Jika perjanjian dilakukan di Indonesia maka, hukum yang berlaku adalah hukum berdasarkan tujuan negara Indonesia yang terkandung dalam pembukaan UUD 1945 alinea ke empat yang berbunyi: Kemudian dari pada itu untuk membentuk suatu pemerintahan negara Indonesia yang melindungi segenap bangsa Indonesia dan seluruh tumpah darah Indonesia dan untuk memajukan kesejateraan umum, mencerdaskan kehidupan bangsa dan ikut melaksanakan ketertiban dunia yang berdasarkan kemerdekaan, perdamaian abadi dan keadilan sosial maka, disusunlah kemerdekaan kebangsaan Indonesia itu dalam suatu Undang-Undang dasar negara Indonesia yang terbentuk dalam suatu susunan dasar negara Indonesia yang terbentuk dalam suatu susunan negara republik Indonesia yang berkedaulan rakyat dengan berdasarkan kepada Ketuhanan yang maha Esa, Kemanusiaan yang adil dan beradab, persatuan Indonesia, dan Kerakyatan yang dipimpin oleh hikmat kebijaksanaan dalam permusyawaratan perwakilan serta kerakyatan yang dipimpin oleh hikmat kebijaksanaan dalam permusyawaratan perwakilan serta dengan mewujudkan suatu keadilan dalam persmusyawaratan perwakilan serta mewujudkan suatu keadilan sosial bagi seluruh rakyat Indonesia (Diantha \& SH, 2016).

Sebagai dasar dan tujuan dari hukum itu sendiri maka, keadilan yang diharapkan adalah sinergi dengan ketentuan dari dasar negara Indonesia begitu juga dalam hal kesepakatan atau kontrak, serta perjanjian. Berdasarkan asas kebebasan, para pihak bebas untuk menentukan isi dari perjanjian kredit sepanjang tidak bertentangan dengan Undang-Undang, ketertiban umum, kesusilaan, dan perdamaian abadi dengan disepakati dan ditandatanganinya perjanjian kredit tersebut oleh para pihak, maka sejak detik itu perjanjian lahir dan mengikat para pihak yang membuatnya sebagai Undang-Undang (Fuady, 2011). Berdasarkan perkembangannya juga maka Perjanjian kredit atau perjanjian utang-piutang pun banyak dijumpai antar pelaku bisnis yang menjalankan roda perusahaan guna memenuhi kebutuhan dalam menjalankan usahanya. Perjanjian 
merupakan suatu peristiwa yang konkret dan dapat diamati, baik perjanjian secara lisan dan tertulis. Maka, hukum kontrak dari dimensi pelaksanaan perjanjian yang dibuat oleh para pihak, artinya hukum perjanjian adalah mekanisme hukum dalam masyarakat untuk melindungi kepentingan yang timbul dalam pembuatan persetujuan demi perubahan masa datang yang bervariasi seperti jual beli (Fuady, 2011).

Hubungan debitur dan kreditur dalam perjanjian utang piutang atau perjanjian pinjam meminjam uang menimbulkan suatu perjanjian pinjam meminjam uang yang menyebabkan adanya suatu perikatan diantara para pihak. Dengan adanya perikatan maka masing-masing pihak mempunyai hak dan kewajiban. Salah satu kewajiban dari debitor adalah mengembalikan utangnya sebagai suatu prestasi yang harus dilakukan. Perjanjian utang piutang bukanlah menjadi suatu masalah dalam dunia usaha bila antara debitur dan kreditur terdapat konsep pemahaman dalam isi perjanjian dan debitur tetap mampu untuk melakukan pembayaran utang. Permasalahan baru timbul apabila debitur tidak cukup efisien dalam menjalankan roda perusahaan dikarenakan krisis financial dan mengalami kebangkrutan atau yang disebut dengan pailit.

Perbendaraan bahasa Belanda, Perancis, Latin dan Inggris istilah pailit mempunyai arti ganda yaitu sebagai kata benda dan kata sifat. Di dalam bahasa Perancis, istilah faillite artinya pemogokan atau kemacetan dalam melakukan pembayaran. Orang yang mogok atau macet atau berhenti membayar utangnya disebut dengan Le Faile. Sedangkan dalam bahasa Latin digunakan istilah failire dan dalam bahasa Inggris digunakan istilah to fail. Di negara-negara yang berbahasa Inggris, untuk pengertian pailit dan kepailitan dipergunakan istilah " bankrupt" dan "bankruptcy", Pailit merupakan suatu keadaan dimana debitor tidak mampu untuk melakukan pembayaran-pembayaran terhadap utang-utang dari para kreditornya (LoPucki, 1983). Keadaan tidak mampu membayar lazimnya disebabkan karena kesulitan kondisi keuangan (financial distress) dari usaha debitor yang telah mengalami kemunduran. Sedangkan kepailitan merupakan putusan pengadilan yang mengakibatkan sita umum atas seluruh kekayaan debitor pailit, baik yang telah ada maupun yang akan ada dikemudian hari. Pengurusan dan pemberesan kepailitan dilakukan oleh kurator dibawah pengawasan hakim pengawas dengan tujuan utama menggunakan hasil penjualan harta kekayaan tersebut untuk membayar seluruh utang debitor pailit tersebut secara proporsional (prorate parte) dan sesuai dengan struktur kreditor.

Salah satu sarana dalam menyelesaikan permasalahan hukum yang menjadi landasan bagi penyelesaian kepailitan termasuk peraturan tentang penundaan kewajiban pembayaran utang yang diatur dalam UU No. 37 tahun 2004. Dimana lembaga kepailitan memberikan suatu solusi terhadap para pihak apabila debitur dalam keadaan berhenti membayar atau tidak mampu membayar. Sehubungan dengan hal 3 tersebut aspek internasional dalam kepailitan akan muncul apabila kepailitan debitur melintasi batas-batas suatu negara, artinya aspek internasional dari kepailitan akan tampak dari adanya harta kekayaan debitur yang terletak atau berada di dua atau lebih negara oleh karena itu, dalam penelitian ini penulis akan menganalisis perbandingan homologasi perdamaian antara kedua negara yaitu, Indonesia dan Amerika Serikat. 
Amerika Serikat adalah salah satu negara demokrasi di dunia yang dicontoh oleh negara lain, karena sistem pemerintahannya dianggap ideal. Sistem pemerintahan Amerika banyak dipakai oleh negara-negara yang baru memperoleh kemerdekaan. Langkah negara ini untuk mencapai suatu julukan sebagai negara adikuasa yang di segani di seluruh dunia. Federalisme di Amerika yang memberikan arti penting bagi masyarakatnya dalam menciptakan kesejateraan bagi masyarakatnya dengan kewenangan yang diberikan kepada pemerintah negara bagian. Berbeda dengan Indonesia, yang beberapa kali menggantikan sistem pemerintahannya. Namun ada kebijakan otonomi daerah yang diberlakukan hanya di daerah khusus di Indonesia. Perbedaan antara sistem hukum antara kedua negara ini, yang mendukung adanya perbedaan dalam menyelesaikan sengketa antara kedua negara, termasuk sengketa bisnis (Amiruddin, 2012).

Globalisasi dan perkembangan zaman maka, perkembangan juga terlihat dalam bisnis antara masyarakat lokal dengan masyarakat internasional. Kemunculan berbagai teknologi menjadi suatu tantangan yang kompleks bagi berbagai sektor. Karena jika persoalan bisnis diabaikan produktivitas akan menurun, namun jika kedua negara memiliki sistem hukum yang berbeda harus ada upaya khusus yang dilakukan oleh yang bersengketa untuk menyelesaikan permasalahan tersebut. Pendekatan yang diciptakan tentu saja untuk menciptakan harmonisasi dari aturan-aturan yang sudah ada, dalam hal kepailitan berarti Indonesia dan Amerika memiliki Undang-Undang yang disebut dengan Undang-Undang Kepailitan dan Penundaan Kewajiban Pembayaran Utang dan Amerika juga mempunyai yang disebut dengan Reorganization Plan dalam Chapter 11 Bankruptcy (Suyatno, 2002). Kedua tersebut menjadi suatu dasar hukum yang digunakan dalam upaya penyelesaian sengketa bisnis internasional. Tulisan ini akan memuat suatu kesenjangan yang sering terjadi dalam suatu perjanjian kontrak antara pelaku bisnis asal Indonesia dengan pelaku bisnis asal United State (US). Terdapat pokok bahasan penelitian yaitu; persamaan dan perbedaan homologasi perdamaian menurut Undang-Undang Kepailitan dengan Reorganization Plan menurut Chapter 11 United State Bankruptcy code.

\section{Metode Penelitian}

Penelitian yang digunakan dalam tulisan ini adalah penelitian hukum normative. Pada penelitian ini, hukum dikonsepkan sebagai suatu kaidah dalam peraturan perundang-undangan atau hukum yang pantas dan berkaitan dengan perjanjian atau kontrak yang dilakukan dalam suatu kerjasama internasional. Untuk mendukung hal tersebut adapun bahan yang digunakan untuk mewujudkan suatu penelitian yang dapat digunakan dalam rangka memenuhi kebutuhan ilmu hukum. Bahan yang digunakan adalah bahan hukum primer, bahan hukum sekunder, bahan hukum sekunder.

1. Bahan hukum primer, merupakan suatu penelitian yang terdiri dari beberapa bahan antara lain:

a. Norma atau kaidah dasar, yaitu pembukaan Undang-Undang dasar 1945

b. Peraturan Dasar Batang tubuh Undang-Undang Dasar 1945 Ketetapan-ketetapan 
Majelis Permusyaratan Rakyat, Undang-undang Kepailitan Nomor 37 Tahun 2004 tentang (PKPU)

c. Peraturan perundang-perundang: Undang-Undang dan peraturan yang setaraf, peraturan pemerintah dan peraturan keputusan Presiden dan peraturan yang setaraf, keputusan Menteri, Peraturan Daerah

d. Bahan hukum yang tidak dikodifikasikan, seperti hukum adat.

e. Yurisprudensi.

2. Kedua, adalah bahan hukum sekuder, merupakan suatu badan hukum yang memberikan penjelasan mengenai bahan hukum primer. Seperti rancangan undangundang, hasil- hasil penelitian, atau pendapat pakar hukum. Bahan hukum ini menggunakan seluruh informasi tentang Undang-Undang Kepailitian serta Chapter 11 United State Bankkruptcy. Bahan yang dikumpulkan melalui buku-buku, bahan bacaan yang dianalisis serta dikelola. Bahan-bahan yang memuat tulisan-tulisan, kritik dai para ahli akademisi yang berkaitan dengan rumusan dari permasalahan serta latar belakang penelitian ini dilakukan (Hutagulung, 2012).

3. Ketiga, Bahan hukum tersier, yaitu bahan yang memberikan petunjuk maupun penjelasan terhadap bahan hukum primer dan bahan hukum sekunder, seperti kamus (hukum), ensiklopedia (Nasution, 2008). Kedua, karena penelitian hukum normatif sepenuhnya menggunakan data sekunder (bahan kepustakaan).

Analisis data merupakan suatu proses pengorganisasian dan mengurutkan data kedalam suatu pola, kategori dan uraian dasar sehingga dapat ditemukan tema dan dapat dirumuskan suatu hipotesis kerja seperti yang disarankan oleh data. Dalam penyusunan penelitian penulis melakukan beberapa tahapan penelitian untuk menyusun penelitian, antara lain: Tahapan awal, Menentukan penelitian yang digunakan yaitu penelitian hukum normatif yang menggunakan pendekatan penelitian antara lain: pendekatan penelitian perundang-undangan, konseptual serta pendekatan kasus (Dewi, 2019). Pendekatan penelitian perundang-undangan yang dimaksud adalah yang berkaitan dengan Undang-Undang Kepailitan dan Reorganization Plan dalam Chapter 11 United State Bankrupty code, serta undang-undang yang terkait dengan peraturan tersebut.

Adapun Penelitian terdahulu yaitu; Akibat Hukum Pengesahan Perdamaian (Homologasi) Terhadap Penundaan Kewajiban Pembayaran Utang Dalam Halm Debitornya Perseroan Terbatas. Penelitian ini menjelaskan tentang Penundaan Kewajiban Pembayaran Utang dan Pengesahan Rencana Perdamaian merupakan langkah hukum yang dilakukan oleh debitor untuk menghindari putusan pailit dan untuk menyelamatkan nama baik debitor serta untuk menyelamatkan harta debitor yang berbentuk Perseroan Terbatas dari kepailitan. Kondisi Perseroan Terbatas yang sedang berada dalam masa. Penundaan Kewajiban Pembayaran Utang, tetap berada dalam keadaan cakap hukum dan segala tindakan hukum yang dilakukan oleh Perseroan Terbatas tetap sah, karena pada saat Perseroan dinyatakan dalam keadaan Penundaan Kewajiban Pembayaran Utang, direksi sebagai pengurus dan perwakilan perseroan tetap dapat melakukan segala tindakan hukum selama tindakan tersebut memperoleh izin dari Pengurus Penundaan Kewajiban Pembayaran Utang yang diangkat oleh Hakim 
Pengawas.

Pengurus pada Penundaan Kewajiban Pembayaran Utang diangkat oleh hakim pengawas untuk membantu debitor melakukan pengawasan terhadap harta debitor untuk melakukan kegiatan perseroan bersama-sama dengan debitor. Imbalan bagi pengurus atau kurator dibayarkan dari harta debitor. Berbeda dengan penelitian tersebut dalam peneltian ini, dasar yang menjadi fokus utama adalah perbandingan hukum kepailitan tentang perdamaian dalam Undang-Undang Nomor 37 Tahun 2004 Tentang Kepailitan dengan Chapter 11 tentang Reorganization Plan.

\section{Hasil dan Pembahasan}

Homologasi merupakan suatu pemberian atau konfirmasi yang berasal dari badan hukum yang mempunyai otoritas resmi seperti mengakhiri suatu kepailitan selain itu, juga digunakan untuk suatu produk untuk mencapai standar untuk hal-hal seperti keselamatan dan dampaknya terhadap lingkungan. Undang-Undang pengesahan oleh hakim yang didasarkan persetujuan dari debitur dan kreditur konkuren untuk mengakhiri kepailitan atau pailit. Secara orisinal, arti pailit adalah seorang pedagang yang bersembunyi atau melakukan tindakan tertentu yang cenderung untuk mengelabui pihak krediturnya. Menurut J.B Huizink kepailitan adalah suatu sitaan umum barangbarang milik debitur untuk kepentingan para kreditor secara bersama. Dampak kelalaian untuk memenuhi keputusan homologasi adalah perusahan tersebut harus dinyatakan pailit berdasarkan Undang-Undang Pasal 291 Nomor 37 Tahun 2004, Tentang Kepailitan dan Penundaan Kewajiban Pembayaran Utang (Royanti, 2020).

Teori Sistem Hukum atau legal system menurut Lawrence Friedman melihat bahwa hukum merupakan sebuah sistem. Dalam bukunya Lawrence Friedman menjelaskan bahwa terdapat tiga hal pokok atau merupakan dasar utama dalam suatu sistem, antara lain: Legal structure, atau struktur hukum, legal substance atau subtansi hukum, dan legal culture atau budaya hukum. Hukum kepailitan di Indonesia tentu saja memiliki persamaan dan perbedaan. Berbeda dengan Amerika Serikat yang memiliki dasar sistem hukum Anglo Saxon, yang merupakan suatu sistem hukum yang didasarkan pada yurisprudensi yaitu keputusan-keputusan hakim terdahulu yang kemudian menjadi dasar suatu putusan (Widiarty, 2016). Awal mula hukum kepailitan di Amerika dimulai saat kebangkrutan pada tahun 1800 dalam suatu kongres, undangundang ini digunakan untuk melindungi debitor dari hukuman penjara karena tidak membayar utang yang disebut dengan insolvency law. Dilanjutkan dengan perubahan Undang-undang beberapa kali pada tahun 1841,1867, 1878,1898,1938 (the Candhler Act), 1867,1898,1978 dan 1984 (Nainggolan, 2014). Awal mula kepailitan di Amerika Serikat dimulai dengan perdebtan yang memiliki tujuan untuk membentuk sebuah aturan tentang kebangkrutan. Perbebatan ini dimulai saat Constitutional Convetion di Philadelphia pada tanhun 1787. kemudian dilanjutkan pada tahun 1800 yang isinya mirip dengan Undang-Undang Kepailitan Inggris. Yang bertujuan untuk melindungi debitor, berkembang terus hingga menjadi suatu sistem yang mengikuti sejarah perkembangannya, kesenjangan dalam kepailitan terjadi karena adanya masalah utang 
antara kreditor dan debitor. Masalah yang baru akan muncul ketika debitor tidak mau membayar utangnya atau karena tidak mampu membayar dan waktunya sudah jatuh tempo. Persamaan yang dimiliki oleh kedua negara adalah (Ekonomi.co.id, 2021): sebelum waktu ini tentu saja ada upaya yang dapat dilakukan:

a. Perdamain di Luar Pengadilan

b. Perdamaian di dalam Pengadilan

c. Gugatan melalui pengadilan

d. Ditagih individual

e. Penundaan pembayaran

f. Perdamaian penundaan pembayaran

Rencana perdamaian ini diajukan kepada kreditor pada saat sebelum adanya putusan PKPU Sementara atau pada waktu rapat kreditor diadakan. Jika di dalam rapat kreditor rencana perdamaian yang diajukan oleh debitor tidak diterima oleh kreditor dengan kuorum yang ditentukan oleh undang-undang, maka debitor menjadi jatuh pailit. Ketentuan kuorum tersebut diatur di dalam Pasal 281 ayat (1) Undang-undang No. 37 Tahun 2004 yang mengatur: Rencana perdamaian dapat diterima berdasarkan:

a. Persetujuan Iebih dari $1 / 2$ (satu perdua) jumlah kreditor konkuren yang haknya diakui atau sementara diakui yang hadir pada rapat kreditor sebagaimana dimaksud dalam Pasal 268 termasuk kreditor sebagaimana dimaksud dalam Pasal 280, yang bersama-sama mewakili paling sedikit $2 / 3$ (dua pertiga) bagian dari seluruh tagihan yang diakui atau sementara diakui dari kreditor konkuren atau kuasanya yang hadir dalam rapat tersebut; dan.

b. Persetujuan Iebih dari $1 / 2$ (satu perdua) jumlah kreditor yang piutangnya dijamin dengan gadai, jaminan fidusia, hak tanggungan, hipotek atau hak agunan atas kebendaan Iainnya yang hadir dan mewakili paling sedikit 2/3 (dua pertiga) bagian dari seluruh tagihan dari kreditor tersebut atau kuasanya yang hadir dalam rapat tersebut.

Jika diperlukan, kreditor dapat menyepakati PKPU Tetap berikut perpanjangannya dengan meminta PKPU Sementara menjadi PKPU Tetap dengan alasan-alasan yang masuk akal dan dapat dipertanggungjawabkan menurut hukum. Hal ini diperbolehkan oleh hukum berdasarkan Pasal 228 Undang-undang No. 37 Tahun 2004 Yang Pada intinya menyatakan bahwa apabila rencana perdamaian belum dapat disepakati atau jika kreditor belum dapat memberikan suaranya mengenai rencana perdamaian tersebut, sedangkan dimungkinkan adanya pertimbangan bahwa rencana perdamaian dapat disetujui dalam sidang selanjutnya, dan waktu PKPU Sementara telah habis, maka dapat dimungkinkan adanya PKPU Tetap, jika kreditor menghendaki dengan hukum yang ditentukan oleh undang-undang. Adapun hukum yang dibutuhkan oleh kreditor untuk meminta PKPU Tetap diatur di dalam Pasal 229 ayat (1) Undang-undang No. 37 Tahun 2004 yang menyebutkan. Pemberian penundaan kewajiban pembayaran utang tetap berikut perpanjangannya ditetapkan Oleh Pengadilan berdasarkan (Kompasiana.com, 2021):

1. Persetujuan lebih dari h (satu perdua) jumlah kreditor konkuren yang haknya diakui 
atau sementara diakui yang hadir dan mewakili paling sedikit 2/3 (dua pertiga) bagian dari seluruh tagihan yang diakui atau sementara diakui dari kreditor konkuren atau kuasanya yang hadir dalam sidang tersebut; dan

2. Persetujuan lebih dari $\mathrm{h}$ (satu perdua) jumlah kreditor yang piutangnya dijamin dengan gadai, jaminan fidusia, hak tanggungan, hipotek atau hak agunan atas kebendaan Iainnya yang hadir dan mewakili paling sedikit 2/3 (dua pertiga) bagian dari seluruh tagihan dari kreditor atau kuasanya yang hadir dalam sidang tersebut. Apabila dalam hal rencana perdamaian diterima oleh Kreditor sebagaimana hukum tersebut dalam Pasal 281 ayat (1) di atas, maka langkah selanjutnya adalah melakukan pengesahan perdamaian atau disebut homologasi.

Persamaan dan pebedaan perdamaian dalam hukum kepailitan di Amerika sendiri memiliki beberapa prinsip dasar dari rencana perdamaian dalam reorganisasi. Setelah periode eksklusivitas, satu dari beberapa pihak dapat mengajukan rencana perdamaian dalam reorganisasi. Pada umumnya sebuah rencana perdamaian dalam reorganisasi haruslah menggambarkan kelompok tagihan dan kepentingan, menentukan kelompok-kelompok tagihan dan kepentingan mana yang kuat dan menjelaskan tindakan yang diusulkan pada kelompok tagihan yang lemah. Terdapat beberapa standar dalam penetapan rencana perdamaian (AdriAn Sutedi, 2014).

1. Pertama, para pihak Yang mendukung rencana perdamaian wajib memenuhi aturan Yang ada dalam Bankruptcy Code, termasuk mematuhi laran dalam keterbukaan dan permohonan penerimaan rencana perdamaian

2. Kedua, rencana perdamaian harus disetujui berdasarkan itikad baik

3. Ketiga, rencana perdamaian harus disetujui berdasarkan kelayakan pembayaran Oleh pihak yang mengajukannya, debitor atau pihak mengeluarkan surat berharga atau memperoleh aset berdasarkan perdamaian, yaitu pengeluaran yang berhubungan dengan rencan perdamaian yang disetujui oleh pengadilan.

4. Keempat, identitas dan kompensasi dari tiap orang dalam yang akan dipertahankan Oleh debitor yang direorganisasi juga harus diperlihatkan sebagaimana identitas dan afiliasi dari individual yang terlibat dalam manajemen setelah penetapan. Bankruptcy Code menghendaki semua tagihan atau kepentingan yang ada dalam kelompok khusus menerima perlakuan yang sama kecuali seorang pemilik tagihan individu menyetujui untuk menerima perlakuan yang tidak sama (Federal Judicial Center, 2020).

\section{Kesimpulan}

Prinsip hukum chapter 11 dalam reorganisasi adalah bahwa debitor dalam prosesnya harus mengajukan rencana reorganisasi yang meliputi semua aspek bisnis operasional perusahaan dan aset serta utang-utangnya, yang mana rencana ini nantinya akan mendapatkan persetujuan dari hakim dan kreditor. Jika sejumlah kreditor tidak setuju dengan rencana tersebut, maka debitor pada akhirnya harus melewati proses likuidasi berdasarkan Chapter 7. Selain debitor, rencana tersebut dapat diajukan oleh trustee, kreditor, Panitia Kreditor, dan pihak lain yang berkepentingan. Perbandingan 
homologasi perdamaian antara hukum kepailitan di Indonesia dan Chapter 11 di Amerika Serikat memiliki persamaan dan perbedaan berdasarkan sistem hukum, subtansi hukum serta budaya hukum. Dalam Chapter yang menjelaskan tentang Reorganisasi Plan yang pada umumnya disebut sebagai reorganisasi kedua negara menentukan pihak ketiga yang ikut menyelesaikan permasalah yaitu Amerika disebut dengan Trustee dan Indonesia disebut dengan kurator. 


\section{BIBLIOGRAFI}

AdriAn Sutedi, S. H. (2014). Hukum Ekspor Impor. RAS. Google Scholar

Amiruddin, H. (2012). Zainal Asikin, 2012, Pengantar Metode Penelitian Hukum, Cetakan ke-6, Edisi Pertama, Penerbit: PT. Raja Grafindo Persada, Jakarta. Google Scholar

Dewi, P. E. T. (2019). Implementasi Penundaan Kewajiban Pembayaran Utang (PKPU) Dalam Kepailitan Ditinjau dari Undang-Undang Nomor 37 Tahun 2004 tentang Kepailitan dan Penundaan Kewajiban Pembayaran Utang. Jurnal Hukum Saraswati (JHS), 1 (2), 280-291. Google Scholar

Diantha, I. M. P., \& SH, M. S. (2016). Metodologi penelitian hukum normatif dalam justifikasi teori hukum. Prenada Media. Google Scholar

Ekonomi.co.id, W. (2021). Perspektif Baru Bisnis \& Ekonomi.

Www.Wartaekonomi.Co.Id. https://www.wartaekonomi.co.id/. Google Scholar

Federal Judicial Center. (2020). Federal District Covid-19 Dashboards: Cases and Trends | Vaccination Rates. Www.Fjc.Gov. https://www.fjc.gov/sites/dehttps://. Google Scholar

Fuady, M. (2011). Pengantar hukum bisnis: Menata bisnis modern di era global. Google Scholar

Hutagulung, S. M. (2012). Praktik peradilan perdata dan Alternatif penyelesaian sengketa. Google Scholar

Kompasiana.com. (2021). kompasiana.com. Kompasiana.Com. Google Scholar

LoPucki, L. M. (1983). The debtor in full control--systems failure under chapter 11 of the bankruptcy code. Am. Bankr. LJ, 57, 99. Google Scholar

Nainggolan, B. (2014). Peranan Kurator dalam Pemberesan Boedel Pailit. Alumni. Google Scholar

Nasution, A. (2008). Standar Kepentingan Umum dalam Permohonan Kepailitan oleh Kejaksaan Menurut Hukum Kepailitan. Google Scholar

Royanti, D. (2020). Teori Gabungan Hukuman dalam Hukum Positif Ditinjau Menurut Hukum Pidana Islam. Uin Ar-Raniry. Google Scholar

Suyatno, R. A. (2002). Pemanfaatan Penundaan Kewajiban Pembayaran Utang Sebagai Upaya Mencegah Kepailitan. Program Pascasarjana Universitas Diponegoro. Google Scholar 
Analisis Perubahan Undang-Undang Investasi Melalui Omnibus Law 2020 dan Dampaknya Terhadap Perijinan Investasi

Widiarty, W. S. (2016). Hukum Perlindungan Konsumen Terhadap Produk Pangan Kadaluwarsa. Komodo Books. Google Scholar

\section{Copyright holder:}

Hanna M. Simanjuntak, Bernard Nainggolan, Wiwik Sri Widiarty (2021)

First publication right:

Jurnal Syntax Admiration

This article is licensed under:

(c) 